\title{
Participative Budget, Information Asymmetry, and Budget Emphasis as a Predictor of Budgetary Slack
}

\author{
Sulastri ${ }^{*}$,Maya Tri Wardani ${ }^{2}$ \\ ${ }^{1,2}$ Malang State University, Jl Semarang 5, Malang 65145, Indonesia \\ *Correspondence author.Email: Sulastri.fe@um.ac.id
}

\begin{abstract}
This study aims to explain the influence of the participative budget (X1), information asymmetry (X2), and budget emphasis (X3) through the possibility of budgetary slack (Y). The populations in this study are all the employers at Region Water Utility Company (PDAM) Malang city and regency. The total population is 872 respondents, while the samples taken in amount of 65 respondents. Sample collecting in this study used a purposive sampling This sampling technique used to determine the samples. The data were analyzed by using double regression and hypothesis test. The result of this study showed that participative budget, information asymmetry, and budget emphasis give a positive and significant influence on the budgetary slack.
\end{abstract}

Keywords: Participative budget, information asymmetry, and budget emphasis, budgetary slack

\section{INTRODUCTION}

Budgetary slack can be defined as the differences between actual sources needed to complete the work effectively and the total sources that are added to complete the work (Falikhatun, 2007). Budgetary slack is a dysfunctional behavior. The behavior which is intentionally done and possibility gives a harmful effect on an organization or individual of an organization (Yasa et al, 2017). Hansen \& Mowen (2006, p. 377) argued that the differences in budget appeared when a manager intentionally estimates the lowest income or increases the budget in the highest amount. Hence, it will possible for the manager to achieve the budget easily. However, it also decreases the risk that will be faced by the manager. Budget affectivity in planning and controlling is decreased due to the bias estimation.

The budgetary slack can be found in the case that happened in 2013 at the district government, Mojokerto. In the report of investigating results, budget plan (RAB) business traveling outside the city of Mojokerto district government was 21, 2 billion and it realized 19, 2 billion or 90,59 percent. In the budget realized, 431, 6 million could not be accountable by the Mojokerto district government. The weirdness was found in the airplane ticket used as a proof. The proof was not suitable with the passengers' manifest data received by BPK from the airline company. The actual trip was by train, but the report stated that the trip was by plane. This aims to achieve budget report document that is an accordance with the budget received. From this case, it can be concluded that there had been an over budget in travel. However, the budget can be lower than it, but it was arranged in a higher amount. This case is showed about budgetary slack activity commited by Mojokerto district government (Beritasatu, 4th of July 2014).

Suartana (2010) defined that some factors are influenced by the budgetary slack, such as budget participation, budget emphasis, organization's commitment, information asymmetry, and job insecurity. Some aspects that will be investigated in this study are budget participation, information asymmetry, and budget emphasis. The first factor that impacts to 
the budgetary slack is budget participation, it is a process of decision making by two or more people. However, the decision result will give a future impact on the people who made it (Tresnayani \& Gayatri, 2016).

Budget existence helps the employers and the first manager to aspire their opinion in arranging the budget. The budget participation gives a chance for the first and the middle manager to conduct budgetary slack to reach the individual welfare (Alfebriano,2013). According to Dharmanegara (2010, p. 23), the manager creates slack to provide a margin of safety to full fill the target that already planned, it is supported by the statement proposed by Young (1985). Young argued that a higher participation given to the employers in budgeting will support them to create the slack.

The study about budget participation through budgetary slack has been conducted by the previous researchers. The result of the previous study showed difference impacts. For example, the study about budget participation correlation conducted by Desmayani \& Suardikha (2016) claimed that budget participation gives a positive impact on the budgetary slack. This result has a contrast with the result of a study conducted by Tresnayani \& Gayatri (2016), whose explained that budget participation gives a negative impact on the budgetary slack.

The second factor which influences the budgetary slack is information asymmetry. Young (1985) stated that information asymmetry frequently happened in a company that has an organizational structure or a complex responsibility unit. The information asymmetry is a condition where a principal has enough information compare with an agent or contrarily (Sugiartha, et al, 2014). The information asymmetry happened when the agents have more information compared with the principal about the organizational unit or agents' responsibility center (Dunk, 1993).

When employers have more information compared with the top management, the first management tends to create a lower target than the higher target as their achievement. The information usually reported by the first manager by showing lower budgetary data than the planning and achievement target which is easily created, i impacts the budgetary slack. Suartana (2010, p. 143) defined that budgetary slack may be increased in information asymmetry condition because it can make the first manager creates budgetary slack. It is supported by study conducted by Rukmana (2013) and Ardanari \& Putra (2014). The result claimed that there was a positive impact between information asymmetry and budgetary slack. In contrast, the study conducted by Falikhatun (2007) stated that information asymmetry has a negative impact on the budgetary slack.

The third factor that is an impact on the budgetary slack is a budgetary emphasis. Budgetary emphasis is the top manager's pressure to the first manager to apply the budget that already created based on the target. In budget emphasis, the manager may create a punishment when the budget result is lower than the target. However, they may also give a reward when the result is higher than the budget target (Kusniawati \& Lahaya, 2017). When employers believe in reward and punishment given is dependent on the budget target achievement, they tend to create budgetary slack through the participation process. The budgetary emphasis happened if the company makes the budget as the only factor that is dominant to measure the employers' performance (Veronica \& Krisnadewi, 2009). The performance measurement based on the budget plan will make the employers work hard to achieve beneficial variance for them. It can be received by created the budgetary slack such as decreasing the income and increasing the budget when creating the budget plan (Sujana, 2010). It is supported by the study conducted by Apriadinata, et. al (2014), and Resen (2014), whose stated that the budget emphasis has a significant impact on the budgetary slack. In contrast, Saputro, et. al (2016) argued that budget emphasis has a negative impact on the budgetary slack.

Agency theory is a concept that explains the contractual relationship between principal and agent, among two or more individual, group, or organization. The principal is a party that makes a decision and gives a mandate to the agent to do all the activities in the name of the principal 
(Jensen \& Meckling, 1976). In this study, the first manager and the middle manager on a duty as an agent, while the top manager as a principal. Agency theory explains that all individual decisions that are considered to their priority may impact the conflict between principal and agent. The conflict happens because in the agency's relation there is a contract conducted by the first and middle manager to the top manager. It is motivated by individual priority and both are frequently contradictory. This theory used to explain the correlation independent variable such as budget participative, information asymmetry, and budget emphasis through the dependent variable, namely budgetary slack.

This study examines, is there a significant impact of partial and simultaneous among the variable of budget participative, information asymmetry, and budget emphasis though the possibility of budgetary slack. The hypothesis presented in this study explained as follows: $\mathrm{H}_{1}$ : budget participative has a positive impact on the budgetary slack, $\mathrm{H}_{2}$ : information asymmetry has a positive impact on the budgetary slack, $\mathrm{H}_{3}$ : budget emphasis has a positive impact to the budgetary slack.

\section{RESEARCH METHOD}

This study applied primer data taken from Region Water Utility Company (PDAM) in Malang and in Malang district in the form of respondents' answers to the questionnaire given. The sample taken by using purposive sampling method with the criteria: 1) The respondent has a position as a head department (the middle manager) or the first manager that was participated in planning and conducting the budget, 2) the respondent has a position or participated in arranging the budget, minimally in a year. Based on those criteria, 65 respondents of samples collected from total populations, 872 respondents who are employers at Region Water Utility Company in Malang district.

The dependent variable in this study is budgetary slack, it is the differences in total budget with manager's best estimation by increasing the burden and decreasing the income. This variable was measured by using the research instrument in the form of a developmental questionnaire proposed by Dunk (1993) and Karsam (2013), measured by the Likert Scale 1-4 with indicators: budget standard, budget behavior, budget strict, budget pressure, budget efficiency, and budget target.

The participative budget is the employers' level of participation, the middle and the first manager in the budget arranging process. Budget participative variable or budget participation in this study is measured by using the developmental instrument proposed by Milani (1957), measured by using a Likert scale 1-4 with indicators: participation in the budget plan, frequency of aspirating the purpose, the impact of the final budget, the importance of contribution, and the frequency of explaining the idea.

Information asymmetry is a condition where unbalance information mastery appeared. The first manager has more information about the company compared with the top manager or contrarily. This variable is measured by using the developmental instrument proposed by Dunk (1993) and Suartana (2010), measured by using Likert scale 1-4 with indicators: company's operational activities, output-input correlation, potential performance, job technique, and able to score the potential effect.

Budget emphasis is the top manager's pressure to conduct the budget based on the target considered as work performance measurement, providing a reward when it is full fill the budget target and providing a punishment when the budget result is lower than the target. This variable is measured by the instrument developed by Armaeni (2012) and Rani (2015) in Irfan, et. al (2016). It is measured by using Likert scale 1-4 with indicators: budget as controlling function, budget as work performance measurement, the ability to reach the budget target, reward when it achieves the budget target, and the budget that is set to increase the performance.

The data in this study were analyzed by using double linear regression with the significant level is $5 \%$. It means the hypothesis of this study will be accepted if the resulting study 
shows the significant value of less than 0,05 . The analysis was conducted by using the software Statistical Product and Service Solution (SPSS). The purpose is to reach a good finding; classic assumption test was conducted before A hypothesis test with double linear regression. Classic assumption test used consists of a normal test, multikolinieritas, and heterokedastisitas test.

\section{RESULTS AND DISCUSSION}

Statistic descriptive analysis gives a picture or description of a data that is seen by the minimum value, maximum, mean, standard deviation, of each study variable. The descriptive analysis result conducted by using Statistical Product and Service Solution (SPSS), from this study variables are explained as follow:

Table 1. The result of Descriptive statistic test

\begin{tabular}{lccccc}
\hline & N & Minimum & Maximum & Mean & Std. Deviation \\
\hline Budgetary Slack & 57 & 10 & 24 & 16,56 & 2,493 \\
\hline Participative budgeting & 57 & 8 & 20 & 13.98 & 2,588 \\
\hline Asymmetry of information & 57 & 8 & 20 & 12,98 & 2,793 \\
\hline Budget Emphasis & 57 & 8 & 20 & 14,81 & 2,695 \\
\hline Valid N (listwise) & 57 & & & & \\
\hline
\end{tabular}

\section{Source: Output SPSS}

The data analysis for hypothesis test consists of a partial test (t-test) and simultaneous test (F statistic test) as follows:

Table 2. The result of regression partial test (t-test)

\begin{tabular}{|c|c|c|c|c|c|c|}
\hline \multicolumn{2}{|c|}{ Model } & \multirow{2}{*}{\multicolumn{2}{|c|}{$\begin{array}{c}\text { Unstandardized } \\
\text { Coefficients }\end{array}$}} & \multirow{3}{*}{$\begin{array}{l}\text { Standardized } \\
\text { Coefficients } \\
\text { Beta }\end{array}$} & \multirow{3}{*}{$\mathrm{t}$} & \multirow{3}{*}{ Sig. } \\
\hline & & & & & & \\
\hline & & B & Std. Error & & & \\
\hline \multirow[t]{4}{*}{1} & (Constant) & 5.078 & 2.081 & & 2.440 & .018 \\
\hline & $\begin{array}{l}\text { Participative budgeting } \\
\text { (XI) }\end{array}$ & .329 & .120 & .342 & 2.742 & .004 \\
\hline & $\begin{array}{l}\text { Asymmetry of } \\
\text { information (X2) }\end{array}$ & .283 & .099 & .317 & 2.861 & .003 \\
\hline & Budget emphasis (X3) & .216 & .114 & .234 & 1.906 & .031 \\
\hline
\end{tabular}

Source: Output SPSS

The variable of budget participative has $\mathrm{t}$-table value 1,674 . Based on the partial test result in table 2, it can be seen that the variable of budget participative has t-test $>\mathrm{t}$ - table $(2,742>1$, 674 ) shown with a positive symbol. In addition, the significant value in the budget participative variable is 0,004 . It shows that the value is higher than 0, 05. From the result, it can be concluded that there is a significant of positive and negative impact between budgets 
participative and budgetary slack. Hence, $\mathrm{H}_{1}$ is accepted.

Participative budget believes in center and first manager who are participated in budgeting their report. When people believe is abused, it will impact the budgetary slack. When the agent reports the information for their individual needed, that because humans tend to avoid the risk (Kahneman \& Tversky, 1979). The result of this study is in line with the study conducted by Desmayani \& Suardikha (2016), Falikhatun (2007), Onsi (1973) and Young (1985), which states that budget participation has a positive impact on the budgetary slack.

The information asymmetry variable has ttable value amount of 1, 674. According to the partial test in table 2, it can be concluded that the information asymmetry variable has $t$ test $>$ $\mathrm{t}$ table $(2,861>1,674)$ and it is proved by a positive symbol. In addition, the significant value on the information asymmetry variable is 0,003 . The value is lower than 0,05 . Therefore, the result claimed that there is a positive and significant impact between information asymmetry and budgetary slack. Thus, $\mathrm{H}_{2}$ is accepted.

Suartana (2010) described that budgetary slack can be higher in information asymmetry conditions, due to the fact that in that condition, the agent will be motivated to create budgetary slack. With higher information asymmetry from the first or center manager on the actual responsibility, motivation, or organizational purposes, it will increase budgetary slack in the budget plan. The agents tend to gives a bias information. For example, making or arranging the budget of the easier target achieved, that caused on budgetary slack (by reporting that the budget is lower than an expected performance). This study is in line with the study conducted by Rukmana (2013), Ardanari \& Putra (2014), which states that there is a positive impact between information asymmetry and budgetary slack.

The budget emphasis variable has t-table amount of 1, 674. According to the part in table 2 , it can be shown that the budget emphasis variable has $\mathrm{t}$ - test $>$ t-table $(1,906>1,674)$ and it is proved by a positive symbol. In addition, the significant value of budget emphasis is 0,031 and it is lower than 0,05 . Thus, it can be concluded that there is a positive and significant impact between budget emphasis and budgetary slack, and $\mathrm{H}_{3}$ is accepted.

Budget emphasis means that there is a pressure felt by businesspersons to the budget target given, and it becomes the higher factor to measure employers' performance. When its condition happened, it will motivate the businesspersons to reach the beneficial variation that can be received by making budgetary slack. The budgetary slack is created by the employers because it impacts their personal needed. Therefore, businesspersons tend to arrange the budget target on a reached easier level when it is used to measure their performance (Lewin, 1970). The result of this study is in line with the study conducted by Veronica \& Krisnadewi (2009)and Resen (2014), stating that the budget emphasis has a positive impact on budgetary slack.

Table 3. Analysis result of the stimulant test ( $F$ statistic test) of regression

\begin{tabular}{llccccc}
\hline Model & & Sum of Squares & df & Mean Square & F & Sig. \\
\hline 1 & Regression & 132.025 & 3 & 44.008 & 10.798 & $.000^{\mathrm{a}}$ \\
\cline { 2 - 7 } & Residual & 216.010 & 53 & 4.076 & & \\
\cline { 2 - 6 } & Total & 348.035 & 56 & & & \\
\hline
\end{tabular}

Source: Output SPSS 
According to the table above, it shows that $\mathrm{F}$ significant value is 0,000 . In test criteria, when the probabilities value $<0,05, \mathrm{H}_{2}$ is accepted. Therefore, it can be concluded that the participative budget (X1), information asymmetry (X2), and budget emphasis (X3) has a significant impact on budgetary slack (Y) and it can be seen from the significant value $\mathrm{F}=$ $0.000<0,05$. When the participative budget (X1), information asymmetry (X2), and budget emphasis (X3) are increased, the budgetary slack will be also increased.

Table 4. The result of determination coefficient test $\left(\mathrm{R}^{2}\right)$

\begin{tabular}{lccccc}
\hline Model & $\mathrm{R}$ & R Square & Square & Estimate & Durbin-Watson \\
\hline 1 & $.616^{\mathrm{a}}$ & .379 & .344 & 2.019 & 1.243
\end{tabular}

Source: Output SPSS

According to the output display of SPSS above, it can be shown that the large of adjusting $R$ square from regression is 0,344 . It means that $34,4 \%$ budgetary slack variation can be explained by 3 independent variables (participative budget, information asymmetry, and budget emphasis). However, 100\% - 34,

\section{CONCLUSIONS}

This study shows that participative budget, information asymmetry, and budget emphasis impact the potential of budgetary slack appearance. Participative budget and budget emphasis has a positive impact on the budgetary slack. It proved that the participative budget, information asymmetry, and budget emphasis became one of the predictors of budgetary slack. It is suggested for the next researcher to applied the qualitative research method in purpose to reach the data in-depth analysis that the study will be more valid in explaining the case happened in the object of the study.

\section{REFERENCES}

[1]. Alfebriano. (2013). Faktor-faktor yang mempengaruhi slack anggaran pada PT. BRI di Kota Jambi. EJurnal Binar Akuntansi, 2(2), 23031522.

[2]. Apriadinata, M. D., Sujana, E., \& Putra, M. P. A. (2014). Pengaruh partisipasi anggaran, penekanan anggaran, komitmen organisasi dan asimetri informasi terhadap slack anggaran dengan kompleksitas tugas sebagai variabel moderasi
$4 \%=65,6 \%$ is explained with the external factors of this study.

(Studi kasus pada bank perkreditan rakyat di kota Singaraja). E-Journal S1 Ak Universitas Pendidikan Ganesha Jurusan Akuntansi Program S1, 2(1), 1-10.

[3]. Ardanari, I. G. A. A. S. C., \& Putra, I. N. W. A. (2014). Pengaruh partisipasi penganggaran, asimetri informasi, self estee dan budget emphasis pada budgetary slack. EJurnal Akuntansi Universitas Udayana, 7(3), 700-715.

[4]. Armaeni. (2012). Analisis pengaruh partisipasi anggaran, informasi asimetri dan penekanan anggaran terhadap senjangan anggaran (budgetary slack). Jurnal Akuntansi Universitas Hasanuddin Makassar, 1-119.

[5]. Dharmanegara, I. B. A. (2010). Penganggaran perusahaan: Teori dan aplikasi. Yogyakarta: Graha Ilmu.

[6]. Desmayani, N. M. M. R., \& Suardikha, I. M. S. (2016). Pengaruh penganggaran partisipatif, locus of control, dan pemberian reward terhadap budgetary slack. E-Jurnal Akuntansi Universitas Udayana, 16(2), 1121-1148. 
[7]. Dunk, A. S. (1993). The Effect of Budget emphasis and information asymmetry on the relation between budgetary participation and slack. The Accounting Review, 68(2), 400-410. doi:10.2307/248408.

[8]. Falikhatun, H. (2007). Interaksi informasi asimetri, budaya organisasi, dan group cohesiveness dalam hubungan antara partisipasi penganggaran dan budgetary slack (studi kasus pada rumah sakit umum daerah se Jawa Tengah). Simposium Nasional Akuntansi X, 1-24, Makassar.

[9]. Hansen, D. R., \& Mowen, M. M. (2006). Management accounting [7th ed]. Siregar., Suripto., Hapsoro., \& Widodo. (Trans). Jakarta: Salemba Empat.

[10]. https://sp.beritasatu.com/home/ bpk-temukan-anggaran-siluman-dipemkab mojokerto/58837. BPK Temukan Anggaran Siluman D Pemkab Mojokerto. Diakses pada 17 November 2018.

[11]. Irfan, M., Santoso, B., \& Effendi, L. (2016). Pengaruh partisipasi anggaran terhadap senjangan anggaran dengan asimetri informasi, penekanan anggaran dan komitmen organisasional sebagai variabel pemoderasi. Jurnal Akuntansi Dan Investasi, 17(2), 158-175. doi:10.18196/jai.2016.0052.158175.

[12]. Jensen, M. C., \& Meckling, W. H. (1976). Theory of the firm: Managerial behavior, agency costs and ownership structure. Journal of Financial Economics, 3(4), 305360. Retrieved from http://ssrn.com/abstract=94043http: //hupress.harvard.edu/catalog/JENT HF.html.

[13]. Kahneman, D., \& Tversky, A. (1979). An analysis of decision under risk. Econometrica, 47(2), 263-291.

[14]. Karsam. (2013). The influence of participation in budgeting on budgetary slack with information asymmetry as a moderating variable and its impact on the managerial performance (A study on yayasan pendidikan dan koperasi in the Province of Banten, Indonesia). International Journal of Applied Finance and Business Studies, 1(1), 28-38. Retrieved from www.ijafbs.com International.

[15]. Kusniawati, H., \& Lahaya, I. A. (2017). Pengaruh partisipasi anggaran, penekanan anggaran , asimetri informasi terhadap budgetary slack pada SKPD kota Samarinda influence of budgetary participation, budget emphasis , information asymmetry on budgetary slack at skpd kota Samarinda. Akuntabel, 14(2), 144156. Retrieved from http://journal.feb.unmul.ac.id/index .php/AKUNTABEL.

[16]. Milani, K. (1975). The relationship of participation in budget-setting to industrial supervisor performance and attitudes: A field study. Accounting Review, $50(2), \quad 1-\quad 274$. doi:10.2307/244709.

[17]. Onsi, M. (1973). Factor analysis of behavioral variables affecting budgetary slack. The Accounting Review, 48(3), 535548. Retrieved from https://www.jstor.org/stable/245151

[18]. Resen, N. S. K. (2014). Pengaruh partisipasi anggaran, self esteem dan budget emphasis terhadap budgetary slack pada hotel berbintang di Denpasar. E-Jurnal Akuntansi Universitas Udayana, 1(10), 1-13.

[19]. Rukmana, P. (2013). Pengaruh partisipasi anggaran dan asimetri informsi terhadap timbulnya budget slack (Studi empiris pada pemerintah kota Padang). Jurnal Akuntansi, 1(1), 1-22.

[20]. Saputra, F., Irianto, B. S., \& Herwiyanti, E. (2016). Faktor yang 
mempengaruhi ketepatan anggaran sektor publik. Soedirman Accounting Review 1, 1(1), 21-39. doi: 10.20884/1.sar.2016.1.2.301.

[21]. Schiff, M., \& Lewin, A. Y. (1970). The Impact of People on Budgets. The Accounting Review, 45(2), 259-268. Retrieved from https://www.jstor.org/stable/244377 ?seq $=1 \&$ cid $=$ pdfreference\#treferences_tab_contents.

[22]. Suartana, I. W. (2010). Akuntansi Keperilakuan. Yogyakarta: Andi Offset.

[23]. Sugiartha, I. P. T., Herawati, N. T., \& Atmadja, A. T. (2014). Pengaruh anggaran partisipatif terhadap budgetary slack dengan informasi asimetri sebagai pemoderasi pada pemerintah Kabupaten Buleleng. E-journal S1 Akuntansi Universitas Pendidikan Ganesha, 2(1). do1:10.23887/jimat.v2i1.3436.

[24]. Tresnayani, L. G. A., \& Gayatri. (2016). Pengaruh partisipasi anggaran, asimetri informasi, kapasitas individu, dan kejelasan sasaran anggaran terhadap potensi terjadinya budgetary slack. E-Jurnal Ekonomi Dan Bisnis
Universitas Udayana, 16(2), 14051432. Retrieved from http://id.portalgaruda.org/?ref=bro wse $\& \bmod =$ viewarticle $\&$ article $=458$ 277.

[25]. Veronica, A., \& Krisnadewi, K. A. (2010). Pengaruh partisipasi penganggaran, penekanan anggaran, komitmen organisasi, dan kompleksitas tugas terhadap slack anggaran pada bank perkreditan rakyat (BPR) Di Kabupaten Badung [Published Bachelor Thesis], Denpasar: Udayana University.

[26]. Yasa, I. G. M., Diatmika, I. P. G., \& Prayudi, M. A. (2017). Pengaruh partisipasi anggaran, penekanan anggaran, kejelasan sasaran anggaran, dan self esteem terhadap senjangan anggaran desa Di Kecamatan Kubutambahan. EJournal S1 Akuntansi Universitas Pendidikan Ganesha, 8(2). doi: 10.23887/jimat.v8i2.13353.

[27]. Young, S. M. (1985). Participative budgeting: The effects of risk aversion and asymmetric information on budgetary slack. Journal of Accounting Research, 23(2), 829-842. doi:10.2307/2490840 